\title{
Teknik Design Labeling Pengembangan Model Kemasan Keripik Salak Pondoh oleh Wanita Tani Srikandi dan Karya Bhakti
}

\author{
Poppy Indrihastuti ${ }^{1)}$, Retno Ayu Dewi Novita ${ }^{2)}$, Eri Yusnita Arvianti ${ }^{3)}$ \\ ${ }^{1)}$ Jurusan Akuntansi, Universitas Tribhuwana Malang \\ 2) Jurusan Manajemen, Universitas Tribhuwana Tunggadewi Malang \\ $\left.{ }^{3}\right)$ Jurusan Agribisnis, Universitas Tribhuwana Tunggadewi Malang \\ Jl. Telaga Warna Blok C - Tlogomas, Malang 565522 \\ *email korespondensi: yusnitaarvianti@yahoo.co.id
}

\begin{abstract}
ABSTRAK
Salak pondoh adalah jenis buah salak yang cukup diminati masyarakat. Kegiatan pengabdian berupa Iptek bagi Masyarakat (IbM) kepada kelompok wanita tani Srikandi dan Karya Bhakti dilakukan dengan tujuan untuk meningkatkan keterampilan produksi, teknik pengemasan, design labelling dan pemasaran guna menunjang omset penjualan dan nilai tambah pada keripik buah salak pondoh yang sedang mereka usahakan. Penelitian pengabdian ini menggunakan metode melalui pelatihan, pendampingan dan pendidikan kepada masyarakat setempat, khususnya bagi kelompok Srikandi dan Karya Bhakti. Hasil pengabdian ini adalah telah diterapkan mesin pengolah vacuum frying, branding teknik pengemasan, dan design labeling pada produk keripik buah salak pondoh.
\end{abstract}

Kata Kunci: pemasaran; teknik pengemasan; design labeling

\section{ABSTRACT}

Pondoh zalacca is one type of zalacca that is quite attractive to the community. Service activities in the form of Science and Technology for the Community (IbM) to Srikandi farmer women's groups and Karya Bhakti are carried out with the aim to improve production skills, packaging techniques, design labeling and marketing to support sales turnover and added value to the pondoh zalacca chips they are seeking. The method used in this service is the method of training, assistance and education to the local community, especially for members of the Srikandi farmer women's groups and Karya Bhakti. The result of this dedication is that the vacuum frying processing machine, packaging technique branding and labeling design have been applied to the salak pondoh chips.

Keywords: marketing; packaging techniques; design labeling.

Cara Mengutip : Indrihastuti, P., Novita, R. A. D., Arvianti, E. Y. (2019). Teknik Design Labeling Pengembangan Model Kemasan Keripik Salak Pondoh oleh Wanita Tani Srikandi dan Karya Bhakti. JAST : Jurnal Aplikasi Sains dan Teknologi, 3 (2),115-121. doi:http://dx.doi.org/10.33366/jast.v3i2.1471 


\section{PENDAHULUAN}

Sektor pertanian menjadi salah satu perubahan yang berorientasi pasar. Orientasi pasar pertanian merubah preferensi konsumen yang menuntut kelengkapan rincian produk, oleh karena itu diperlukan penggerak sektor pertanian yang mencakup perubahan pemikiran dari usaha tani menjadi produk agroindustri yang berorientasi pada pasar berbasis pertanian. Beberapa tujuan dalam mencapai pengembangan agroindustri berkelanjutan adalah: (a) menumbuhkan dan mengembangkan pendirian industri pertanian baru dalam bidang agroindustri, (b) meningkatkan perekonomian dalam sektor pertanian, (c) meningkatkan nilai jual produk agroindustri (d) membuka kesempatan kerja bagi pengangguran serta menungkatkan pendapatan dalam bidang agroindustri (Soekartawi, 2005).

Produk Home Industry menjadi pengaruh dalam peningkatan pendapatan dalam segi perekonomian masyarakat, hal tersebut menjadi salah satu penyerapan tenaga kerja. Dalam hal ini, produk kripik buah dapat memberikan nilai tersendiri pada buah-buahan yang telah disortir sehingga harga, kualitas, dan kuantitas buah tersebut memiliki harga yang relativ rendah, dengan usaha pengolahan buah menjadi produk kripik dapat meningkatkan laju perekonomian bagi petani buah sebagai sumber pendapatan. Laba maksimum dapat diperoleh dengan cara perusahaan mengatur biaya produksi dan operasi serendah mungkin, serta dapat menentukan harga jual dengan keuntungan maksimum, dan volume penjualan semakin naik (Wibowo, 2013).

Desa Sumbergondo, Kecamatan
Bumiaji dan Desa Purworejo Kecamatan Ngantang salah satu contoh desa dengan wilayah pegunungan. Suhu dingin dengan udara sejuk, serta panorama alam yang indah. Kondisi geografis cukup mendukung dalam pemanfaatan lahan sebagai budidaya tanaman hortikultura. Perubahan cara pandang masyarakat dalam bercocok tanam ini menyebabkan permasalahan baru yang dihadapi oleh kelompok tani di Desa Sumbergondo Kecamatan Bumi Aji dan Desa Purworejo Kecamatan Ngantang.

Usaha Home Industri keripik buah salak membutuhkan modal dan peralatan yang memadai guna menunjang keberhasilan produk yang berkelanjutan. Kotler dan Amstrong (2012) mengartikan kemasan sebagai pelindung produk yang ada didalamnya serta melibatkan desain dalam proses membuat sebuah kemasan. Kelompok ibu petani buah salak di Desa Sumbergondo, adalah upaya sebagai contoh kelompok ibu rumahtangga yang mau dan mampu diajak bangkit dan berusaha meningkatkan pendapatan keluarga melalui usaha keripik salak pondoh yang diberi nama atau sebutan keripik salak Nacia.

Menurut Hartono dan Peni (2012) menjelaskan bahwa kemasan merupakan identitas suatu produk dan membuat orang lain untuk lebih mudah memilih suatu barang.

$$
\text { Menurut Tjiptono (1999:106) }
$$

bahwa kemasan memiliki beberapa manfaat dan tujuan pada produk yaitu:

1. Melindungi produk (protection)

2. Mempermudah penggunaan produk (operation)

3. Memberikan kemudahan dalam pemakaian ulang (reusable) 
4. Sebagai daya tarik (promotion) untuk produk berupa aspek artistik, warna, bentuk, dan desain

5. sebagai salah satu identitas produk (image)

6. memudahkan proses distribusi (shipping)

7. dapat memberikan informasi (labelling) yang menyangkut kompisisi, kadaluarsa, kandungan gizi, serta design produk berkaitan pada kemajuan teknologi yang dapat didaur ulang.

Berdasarkan uraian yang disebutkan, kegiatan pengabdian ini bertujuan untuk memberikan pendampingan, pelatihan dan pendidikan kepada masyarakat dalam strategi pemasaran, khususnya dalam hal teknik pengemasan dan design labelling pada produk yang diproduksi. Dengan adanya pendampingan dan pendidikan ini, maka diharapkan industri rumahtangga di Desa Tirtomulyo dapat berkembang dan berekspansi ke usaha yang berskala besar serta lebih luas.

\section{METODE KEGIATAN}

Metode kegiatan menggunakan metode studi kasus.

\section{- Pendidikan Masyarakat}

Untuk kegiatan :

a). Metode pendampingan,

b). Pendidikan masyarakat (khususnya bagi anggota kelompok wanita tani).

Metode pendampingan yang dilakukan berkaitan pada upaya tahaptahap pemasaran, pendampingan dilakukan dengan proses pembuatan label, pendampingan pada proses pengemasan dan proses pembuatan design labelling.
Menurut Kotler dan Amstrong (2012) mengartikan kemasan sebagai pelindung produk yang ada didalamnya serta melibatkan desain dalam proses membuat sebuah kemasan. Pendampingan proses promosi untuk produk serta pendampingan pada strategi pemasaran produk dapat menghasilkan produk dengan kualitas yang dapat diminati setiap konsumen. Metode pendampingan dan pelatihan, diharapkan masyarakat dapat mengerti setiap tahapan demi tahapan pemasaran berbagai macam produk pertanian yang dihasilkan, mempraktikkan secara langsung tahapan demi tahapan proses pemasaran produk yang baik dan benar, khususnya dalam hal teknik pengemasan dan design labelling. Sehingga, metode pendidikan dapat dilakukan dengan melibatkan peranan masyarakat secara langsung untuk mengetahui tahapan proses atau tahapan pemasaran produk. Adapun teknik pengumpulan data dilakukan dengan cara terjun langsung dalam proses produksi keripik buah salak pondoh. Survei dilakukan pada masyarakat sekitar dan pada kelompok tani ibu rumahtangga selaku perintis berdirinya usaha produksi keripik buah salak pondoh.

\section{KARYA UTAMA}

Industri rumah tangga dalam pembuatan keripik buah salak pondoh yang dirintis oleh kelompok tani ibu rumahtangga Srikandi Desa Sumbergondo dan Karya Bhakti Desa Purworejo telah berjalan dari beberapa tahun yang lalu dan hingga kini masih memproduksi kripik buah salak pondoh. Akan tetapi, industri rumahtangga tersebut terhambat dengan 
kegiatan produksi dan pemasaran tidak maksimal, hal tersebut disebabkan belum adanya teknik pengemasan dan design labelling yang dipatenkan oleh industri rumahtangga yang dikeloka oleh kelompok Wanita Tani Srikandi dan Karya Bhakti. Menurut Krasovec dan Kimchuk (2007), Desain kemasan merupakan sebuah sarana berkomunikasi dengan semua orang yang mengkaitkan bentuk, warna, tipografi, citra, dan lainlain dalam membungkus serta melindungi produk yang akan dipasarkan secara kreatif dan bernilai estetik. Hal itu menyebabkan ekspansi usaha menjadi terhambat.

\section{ULASAN KARYA}

Kegiatan ini dilakukan untuk memberikan pelatihan, pendidikan serta pendampingan sekaligus cara dalam mengatasi pemecahan masalah yang berkaitan dengan strategi pemasaran keripik buah salak pondoh yang belum maksimal. Hal ini dikeluhkan sebagian produsen dengan mayoritas anggota kelompok tani ibu rumahtangga dengan teknik pengemasan dan design labelling belum dipatenkan sebagai design resmi. Oleh karena itu, beberapa hal yang belum ada yaitu izin produksi dan nomor register dalam industri dianggap sebagai salah satu hal penghambat pengembangan usaha. Pendampingan pada industri keripik buah salak pondoh kelompok wanita tani Srikandi dan Karya Bhakti dilakukan dengan ikut terlibat langsung dalam proses pengolahan dan proses produksi. Dari hasil pendampingan diketahui bahwa teknologi yang digunakan dalam produksi keripik buah salak pondoh di kedua kelompok wanita tani tersebut masih menggunakan peralatan sederhana karena dari segi mekanisasi peralatan masih dioperasikan secara manual, pada tahapan yang dilakukan dari beberapa proses produksi. Hal ini menyebabkan jumlah target produksi yang dihasilkan perhari tidak menentu, karena jumlah bahan baku yang tidak mencukupi dalam target produksi. Selain itu, dilihat dari tahapan proses produksinya, cara pembuatan keripik buah salak pondoh tersebut relatif mudah dan tidak memerlukan banyak keahlian khusus. Akan tetapi, melalui kegiatan pengabdian ini, kedua kelompok wanita tani tersebut telah mendapatkan alat yang diberikan tim kepada kelompok wanita tani Srikandi dan Karya Bhakti berupa mesin pengolah keripik buah salak yang modern, sehingga dapat menghasilkan keripik buah salak pondoh yang diminati konsumen dari segi aroma, rasa dan warna. Begitu pula halnya dengan teknik pengemasan dan design labelling telah dilakukan pelatihan dan cara membuat kemasan yang sesuai dengan menggunakan pengemas Alummunium Foil dan design label "NaCia". Berikut ini penyerahan alat, pelatihan, pendidikan, dan pendampingan yang dilakukan tim kepada kelompok Wanita Tani Srikandi dan Karya Bhakti :

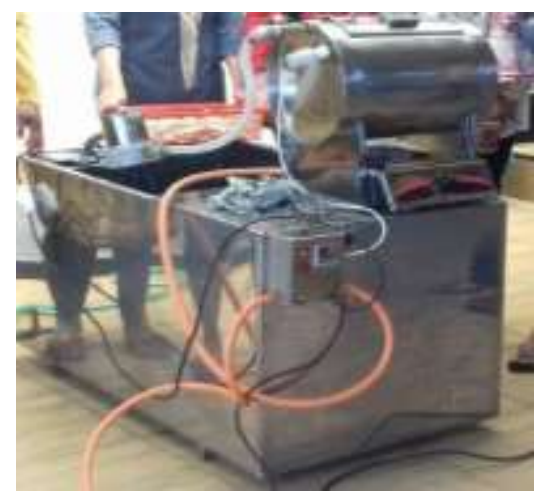

Gambar 1. Mesin vacum penggoreng kripik buah salak 


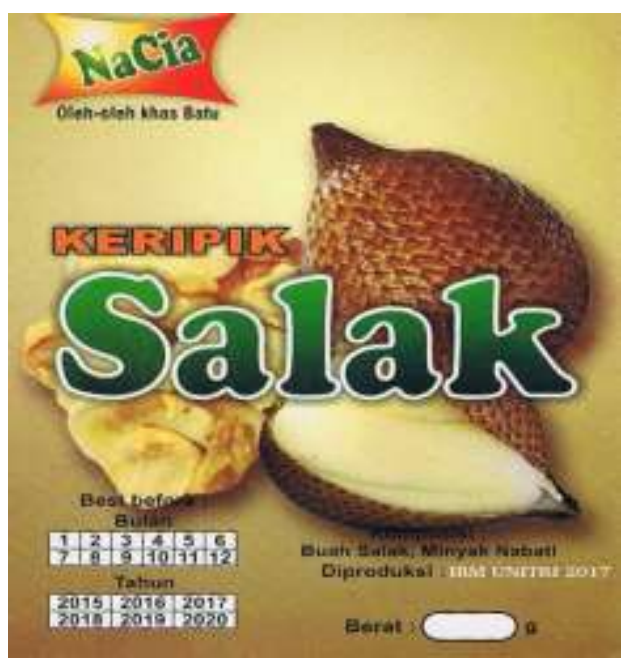

Gambar 2. Design Labelling kemasan keripik buah salak

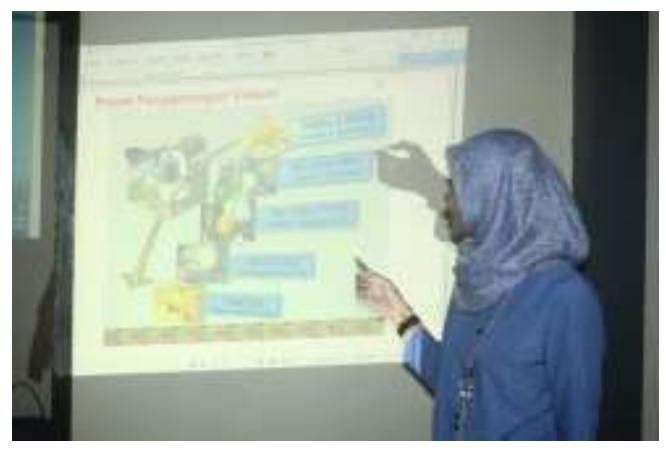

Gambar 3. Pendidikan oleh tim kepada kedua kelompok industri rumah tangga

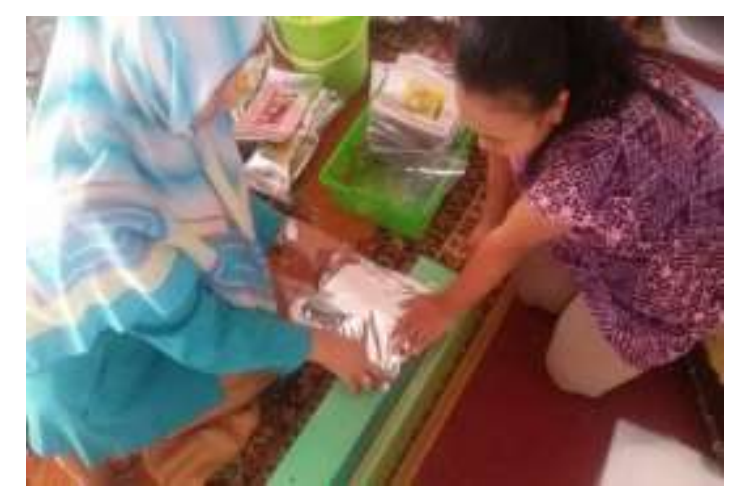

Gambar 4. Pendampingan dalam teknik pengemasan menggunakan allumunium foil

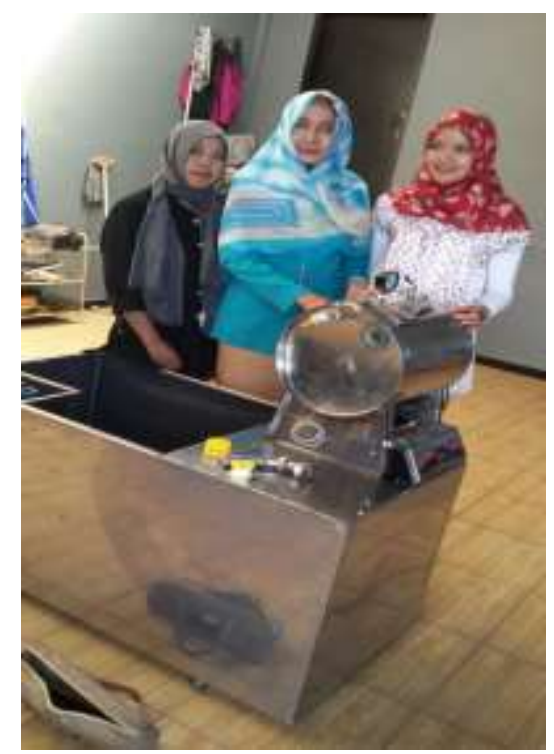

Gambar 5. Serah terima alat dari tim kepada kelompok industri rumahtangga kripik buah salak

Proses pendidikan, pelatihan, dan pendampingan yang telah dilakukan dalam kegiatan ini adalah dimulai dari proses produksi pembuatan keripik buah salak hingga pada proses pemasaran. Tahapan proses produksi pembuatan keripik buah salak adalah sebagai berikut:

1. Kulit salak dikupas kemudian salak dipisahkan daging dan bijinya.

2. Buah salak dibagi menjadi dua.

3. Buah salak direndam pada air dengan campuran kapur sirih. Perendaman dilakukan selama 5-6 jam supaya tekstur buah salak yang dihasilkan memberikan tekstur lebih renyah.

4. Buah salak dicuci menggunakan air hingga bersih, lalu ditiriskan.

5. Salak yang sudah dicuci selanjutnya dilakukan peroses penggorengan dengan menggunakan mesin penggoreng kedap udara (Vacum Frying) yang sudah diisi minyak goreng. Keripik salak digoreng pada mesin vacum frying selama 1,5 jam dengan tekanan $-68 \mathrm{cmHg}$. 
6. Selanjutnya keripik yang telah kering akan dilakukan proses penirisan dan pengemasan dengan menggunakan alummunium foil kemudian siap dipasarkan.

Pengolahan buah salak diatas secara singkat dapat dilihat pada Flow Chart Pengolahan Keripik Salak berikut ini:

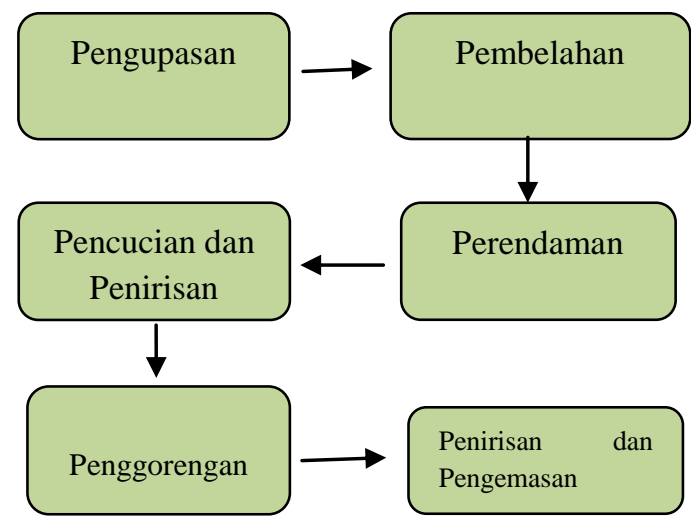

\section{Gambar 6. Flow Chart Pengolahan Keripik Salak}

Selain pendidikan, pelatihan dan pendampingan produksi keripik buah salak, pendampingan dilakukan dengan mencari informasi sebanyak - banyaknya yang terkait dengan sistem pemasaran produk keripik buah salak tersebut. Dari hasil pendampingan dapat diketahui bahwa bentuk promosi yang dilakukan masih manual dan sederhana, yaitu promosi dari mulut ke mulut. Hal tersebut membuat produsen terhambat dalam mengembangkan usahanya secara cepat.

Pendampingan dilakukan dengan tujuan pengembangan design labelling produk dengan keinginan produsen. design labelling dan teknik untuk pengemasan produk dapat berpengaruh terhadap persaingan pasar serta minat konsumen pada suatu produk. Setelah dimusyawarahkan dan disepakati dengan para produsen serta melalui perbaikan perbaikan melalui tahap demi tahap yang cukup mendasar, pada akhirnya, design labelling yang telah disepakati. Design labelling yang digunakan sebagai branding produk keripik buah salak dan kemasan yang lebih menarik. Meskipun tampak sederhana, design labelling tersebut diharapkan dapat menjadi ciri khas serta meningkatkan minat konsumen. Selain itu, daya beli konsumen diharapkan dapat lebih baik lagi dengan adanya pengemasan produk yang lebih menarik. Dari gambar 2 diatas dapat dilihat bahwa design label yang dibuat telah mencantumkan nama $\mathrm{NaCia}$ atau brand dagang kripik buah salak pondoh yang diproduksi oleh kelompok wanita tani Srikandi dan Karya Bhakti sebagai identitas, serta kelengkapan produk yang meliputi : komposisi, jangka waktu konsumsi, dan ukuran berat (satuan gram).

Selain pelatihan, pendampingan dan pendidikan mengenai proses produksi pembuatan keripik buah salak dan design labelling, pelatihan, pendidikan dan pendampingan mengenai teknik pengemasan juga diberikan. Pelatihan, Pendampingan dan pendidikan mengenai teknik pengemasan keripik buah salak ini dilakukan dengan tujuan supaya mitra dapat mengetahui kapan dan bagaimana ciri - ciri produk kripik yang sudah digoreng dapat dikemas. Jenis pengemas yang digunakan adalah alummunium foil. Keripik buah salak yang telah siap untuk dikemas adalah keripik buah salak yang telah melalui proses penirisan dan sudah kering, sehingga keripik siap dikemas dan kriik buah salak dilakukan proses penimbangan, kemudian dikemas 
menggunakan kemasan yang telah disediakan, dan direkat menggunakan sealer. Selain dikemas, keripik buah salak harus diberi label dengan tujuan sebagai brand dagang atau identitas keripik buah salak pondoh tersebut. Tujuan memberi kemasan pada produk salah satu upaya pengembangan produk yang dihasilkan dapat bertahan dalam rentang waktu yang agak lama.

\section{DAMPAK DAN MANFAAT KEGIATAN}

a. Dengan adanya kegiatan pengabdian masyarakat ini, dapat memberikan pengetahuan dan inspirasi dalam pengembangan dan pemanfaatan buah dengan kualitas relatif rendah.

b. Dapat meningkatkan perekonomian masyarakat

c. Memberikan peran dan penyerapan tenaga kerja.

\section{KESIMPULAN}

Kesimpulan dari kegiatan pengabdian masyarakat ini adalah pelatihan, pendampingan dan pendidikan masyarakat yang telah direncanakan dan disusun sebelumnya suapay dapat berjalan dengan lancar dan baik. Hal itu terbukti dengan tercapainya tujuan kegiatan yang telah direncanakan oleh tim pengabdian yaitu dengan melakukan pelatihan, pendidikan dan pendampingan dalam pembuatan design label dan teknik pengemasan pada produk keripik buah salak pondoh yang diberi nama atau brand dagang $\mathrm{NaCia}$. Ke depannya, dengan adanya design label dan teknik pengemasan yang diberikan pada produk keripik buah salak pondoh diharapkan dapat lebih mempermudah pemasaran produk dan perluasan jaringan pasar industri pada sektor olahan hasil tanaman pangan ini.

\section{DAFTAR PUSTAKA}

[1]. Hartono, A., \& Pramono, Peni. (2012). Kemasan Apik Goda Selera dan Dongkrak Penjualan. Jakarta: PT Elex Media Komputindo.

[2]. Anonim. 2014. Mesin Produksi

Keripik Buah. Available : http://www.vacuumfrying.com. [25 Mei 2011].

[3]. Kotler, Philip dan Gary Amstrong. 2012. Prinsip-Prinsip Pemasaran. Edisi 13. Jilis 1. Jakarta: Erlangga.

[4]. Marianne Rosner Klimchuk, \& Sandra A. Krasovec. (2007). Desain Kemasan. Jakarta: Erlangga.

[5]. Soekartawi. 2005. Pengantar Teori Agroindustri. PT. Raja Grafindo Persada.Jakarta.

[6]. Sudiyono, A. 2004. Pemasaran Pertanian. UMM Press, Malang

[7]. Tjiptono, F. 1999. Strategi Pemasaran. Yogyakarta: Andi Offset.

[8]. Wibowo, Singgih. 2013. Pedoman Pengelolaan Perusahaan Kecil. Penebar Swadaya. Jakarta. 